\title{
PEMBAHARUAN UTANG KREDITUR KEPADA DEBITUR SEBAGAI BENTUK PENJATUHAN PUTUSAN PAILIT
}

\author{
Oleh : \\ Sri Lestari*, Rizki Kurniawan** \\ *Mahasiswa Fakultas Hukum Universitas Gresik \\ **Dosen Fakultas Hukum Universitas Gresik \\ e-mail: rifkifhug@gmail.com / tariary39@gmail.com
}

\begin{abstract}
ABSTRAK
Pembaharuan utang atau novasi merupakan suatu perjanjian yang menyebabkan hapusnya perikatan dan pada saat yang bersamaan timbul perikatan lainnya yang ditempatkan sebagai pengganti perikatan sebelumnya. Penundaan Kewajiban Pembayaran Utang adalah suatu masa yang diberikan oleh UndangUndang melalui hakim Pengadilan Niaga yang dimana dalam masa tersebut kreditor dan debitor diberikan kesempatan untuk memusyawarahkan cara-cara pembayaran utang debitor dengan cara memberikan rencana pembayaran seluruh atau sebagian utangnya, termasuk apabila perlu untuk merestrukturisasi utangnya tersebut, dan disinilah akan lahir perikatan baru atau terjadi sebuah novasi.

Namun demikian, melalui PKPU ketentuan Undang-undang Nomor 37 Tahun 2004 juga dapat mempercepat debitor untuk sampai pada tahapan kepailitan. Dalam Undang-undang ini, bila debitor dan kreditor tidak dapat mencapai kesepakatan pembayaran utang pada masa PKPU Sementara, maka debitor dapat dinyatakan pailit. Demikian pula bila PKPU Tetap gagal dilaksanakan, debitor pun akan berujung pada kepailitan.
\end{abstract}

Kata Kunci : Pembaharuan Utang, Penundaan Kewajiban Pembayaran Utang, Kepailitan .

\begin{abstract}
Renewal of the debt is an agreement that led to the abolishment of engagement and at the same time raised other arrangement that replace the previous engagemen. Suspension of payment is a period provided by Law through a Commercial Court judge in which during that period creditor and debtor are given the opportunity to deliberate the ways to repay debtor debt by providing a plan to repay all or part of its debt, including when it needed to restructure the debt, and this is where the new covenant or innovation will be born.

However, through Suspension of Payment of Law No. 37 Year 2004 also can speed up debtors to reach the stage of bankruptcy. In this Law, if the debtor and creditor can not reach an agreement on debt repayment during the Temporary Suspension of payment, the debtor can be declared bankrupt. As well, if Suspension of payment continues to fail, debtors also will end in bankruptcy.
\end{abstract}


Keywords: Renewal of the debt, Suspension of Paymen, bankruptcy .

\section{A. PENDAHULUAN}

Sebagai negara berkembang Indonesia termasuk negara yang giat dalam membangun segala aspek kehidupan, termasuk untuk membangun perekonomian bangsa. Hal ini tidak lepas dari peran masyarakat yang sangat membantu meningkatkan perekonomian di Indonesia dengan menjalankan berbagai usaha maupun bisnis. Dalam menjalankan usaha tersebut tentu sangat membutuhkan biaya yang besar, banyak pelaku usaha yang tidak mampu memenuhi kebutuhan dalam menjalankan usahanya sehingga membutuhkan bantuan dari pihak lain maupun lembaga keuangan untuk bantuan modal, kerjasama, simpanan dan lain sebagainya. Setiap orang memerlukan uang atau dana untuk membiayai keperluan hidupnya. Demikian juga halnya dengan suatu badan hukum, terutama sebuah perusahaan, perusahaan membutuhkan banyak dana untuk melangsungkan usaha yang dijalankan. Dalam kehidupan memang tersedia sumber-sumber pendanaan bagi seseorang atau badan hukum yang ingin memperoleh pinjaman (borrowing,loan atau credit). Apabila seseorang atau badan hukum memperoleh pinjaman dari pihak lain, pihak yang memperoleh pinjaman itu disebut dengan Debitur, sedangkan pihak yang memberikan pinjaman itu di sebut dengan Kreditur. Berdasarkan Pasal 1 angka 3 Undang-Undang Kepailitan dan Penundaan Kewajiban Pembayaran Utang (selanjutnya disebut PKPU) bahwa debitor adalah orang yang mempunyai utang karena perjanjian atau undang-undang yang pelunasannya dapat ditagih dimuka pengadilan $^{1}$ sedangkan Pasal 1 angka 2 Undang-Undang Kepailitan dan PKPU kreditor adalah orang yang mempunyai piutang karena perjanjian atau undangundang yang dapat ditagih dimuka pengadilan $^{2}$. Tidak dapat dipungkiri bahwa keberadaan kreditur sangat berperan untuk pembiayaan maupun fasilitas penyediaan dana terutama bagi pelaku usaha. Pelaksanaan peminjaman modal yang tidak sesuai dengan yang diperjanjikan merupakan bentuk dari cidera janji atau wanprestasi. Wanprestasi merupakan keadaan ketika salah satu pihak tidak memenuhi atau lalai melaksanakan kewajiban (prestasi) sebagaimana yang ditentukan dalam perjanjian yang dibuat antara kreditor dengan debitor. ${ }^{3}$ Ketidakmampuan debitor dalam membayar utangutangnya dapat mengakibatkan debitor terancam pailit yang berdampak pada dilikuidasinya harta kekayaan debitor. Rencana perdamaian yang diajukan oleh Debitor adalah merupakan suatu hak dan dapat diajukan pada waktu mengajukan permohonan PKPU atau setelah menawarkan suatu perdamaian kepada Kreditor sebagaimana diatur dalam Pasal 265 dan 266 UndangUndang Nomor 37 Tahun 2004 tentang Kepailitan dan PKPU. Dari segi solvabilitas perusahaan tidaklah mungkin untuk membayar kewajibannya pada jangka waktu terdekat, namun diharapkan dengan adanya restrukturisasi tersebut perusahaan dapat mengangsur

1 Elyta Ras Ginting, Hukum Kepailitan Teori Kepailitan, Sinar Grafika, Jakarta, 2018, h. 139.

${ }^{2}$ Ibid, h. 172.

3 Salim HS, Hukum Kontrak: Teori dan Teknik Penyusunan Kontrak, Sinar Grafika, Jakarta, 2003, h. 98. 
pembayaran kewajibannya kelak apabila perusahaan tersebut telah sehat undang-undang memberikan pilihan berupa upaya permohonan Penundaan Kewajiban Pembayaran Utang (selanjutnya disebut PKPU) sebagai upaya mencegah terjadinya pailit.

Pada hakikatnya PKPU bertujuan untuk melakukan perdamaian antara debitor dengan para kreditornya dan menghindarkan debitor yang telah atau akan mengalami insolven dari pernyataan pailit. Arti insolvensi dapat kita temukan dalam Penjelasan Pasal 57 ayat (1) Undang-Undang Nomor 37 Tahun 2004 tentang Kepailitan dan PKPU yang berbunyi "Yang dimaksud dengan insolvensi adalah keadaan tidak mampu membayar."

Selama berlangsungnya PKPU, menurut Pasal 242 ayat (1) Undangundang Nomor 37 Tahun 2004, debitor tidak dapat dipaksa untuk membayar utang-utangnya. Selain itu, semua tindakan eksekusi yang telah dimulai dalam rangka pelunasan utang harus ditangguhkan. Dapat diartikan bahwa keadaan ini berlangsung baik selama PKPU Sementara maupun selama PKPU Tetap. Ketentuan demikian itu sangat melindungi kepentingan debitor yang bermaksud untuk menunda pembayaran utang yang dimilikinya. Namun demikian, melalui PKPU ketentuan Undang-undang Nomor 37 Tahun 2004 juga dapat mempercepat debitor untuk sampai pada tahapan kepailitan. Dalam Undang-undang ini, bila debitor dan kreditor tidak dapat mencapai kesepakatan pembayaran utang pada masa PKPU Sementara, maka debitor dapat dinyatakan pailit. Demikian pula bila PKPU Tetap gagal dilaksanakan, debitor pun akan berujung pada kepailitan.

\section{B. METODE PENELITIAN}

Didalam penelitian ini penulis menggunakan metode penelitian yuridis normatif yaitu dilakukan dengan cara menelaah teori-teori hukum, konsep-konsep hukum, asasasas hukum serta mengkaji peraturan perundang-undangan yang berhubungan dengan pokok permasalahan yang telah dirumuskan dalam penelitian ini. Untuk mencari jawaban atas pokok permasalahan dalam penelitian ini, penulis menggunakan tiga pendekatan masalah yaitu Pendekatan Perundang-undangan (Statute Approach), Pendekatan Konseptual (Conceptual Approach), Pendekatan Perbandingan

(Comparative Approach).

\section{KAJIAN PUSTAKA}

Kepailitan sebagai suatu Lembaga Hukum Perdata Eropa yang merupakan realisasi dari dua asas pokok dalam Hukum Perdata Eropa sebagaimana tercantum dalam Pasal 1131 dan 1132 KUH Perdata.

Pasal 1131 KUH Perdata, berbunyi sebagai berikut :

"Segala kebendaan di berutang baik yang bergerak maupun yang tak bergerak, baik yang sudah ada maupun yang baru akan ada di kemudian hari, menjadi tanggungan untuk segala perikatannya perserorangan".

Pasal 1132 KUH Perdata, berbunyi sebagai berikut :

"Kebendaan tersebut menjadi jaminan bersama-sama bagi semua orang yang mengutang padanya; pendapatan penjualan benda-benda itu dibagi-bagi menurut keseimbangan, yaitu menurut besar-kecilnya piutang masing-masing, kecuali apabila diantara para berpiutang itu ada alasan-alasan yang sah untuk didahulukan".

Asas yang terkandung dalam kedua pasal tersebut adalah : 
a. apabila si Debitur tidak mampu membayar utangnya dengan sukarela walaupun telah ada putusan pengadilan yang menghukumnya supaya melunasi utangnya, atau kerena tidak mampu untuk membayar seluruh utangnya, maka harta bendanya disita untuk dijual dan hasil penjualan itu dibagibagikan kepada semua krediturnya menurut besar kecilnya piutang masing-masing, kecuali ada alasanalasan yang sah untuk didahulukan;

b. semua Kreditur mempunyai hak yang sama;

c. tidak ada nomor urut dari Para Kreditur yang didasarkan atas timbulnya piutang mereka.

Untuk melaksanakan asas yang terkandung dalam Pasal 1132 KUH Perdata tersebut, maka pembuat undang-undang menciptakan Peraturan Kepailitan yakni Faillissement Verordening (S.1905-217 jo S.1906348) yang sekarang dikenal dengan Undang-Undang Kepailitan Nomor 4 Tahun 1998 jo Undang-Undang Kepailitan Nomor 37 Tahun 2004 .

Kepailitan merupakan lembaga penyelesaian utang-piutang antara kreditur dengan debitur. UndangUndang Kepailitan sendiri tidak menjelaskan mengenai rumusan atau pengertian, maupun definisi tentang kepeilitan atau pailit.

Menurut Black'k Law Dictionery, Bankrupt adalah "The state or condition of who is unable to pay his debts as they are, or become, due. The term include a person againts whom an involuntary petition has been filed, or who has filed avoluntary petition, or who has been adjkudged a bankrupt". Kurang lebih mengandung arti suatu keadaan atau kondisi mengenai seseorang yang tidak mampu membayar hutang-hutangnya ketika atau sejak hutang-hutang tersebut telah jatuh tempo.

Menurut kamus hukum, pailit adalah suatu keadaan dimana seseorang debitur telah berhenti membayar utangutangnya. Setelah orang yang demikian atas permintaan para kreditornya atau atas permintaan sendiri oleh pengadilan dinyatakan pailit, maka harta kekayaannya dikuasai oleh Balai Harta Peninggalan (BHP) selaku curatrice (pengampu) dalam urusan kepailitan tersebut untuk dimanfaatkan bagi semua kreditor.

Menurut Terminologi Hukum InggrisIndonesia, Bankruptcy adalah keadaan tidak mampu membayar hutang dalam mana harta yang berhutang diambil oleh penagih atau pesero-pesero, status seseorang yang secara hukum, dinyatakan tidak mampu membayar utang-utangnya.

Menurut Kamus Hukum Ekonomi, Bankrupt, pailit, Bangkrut adalah suatu keadaan debitur yang dinyatakan dengan putusan Hakim bahwa ia dalam keadaan tidak mampu membayar utang-utangnya.

Munir Fuady menyatakan pada umumnya dalam masyarakat yang dimaksud bangkrut atau pailit adalah suatu sitaan umum atas seluruh harta debitur agar dicapainya perdamaian antara debitur dan para kreditur atau agar harta tersebut dapat dibagi-bagi secara adil di antara para kreditur. ${ }^{4}$

Sebagai kesimpulan, pailit adalah keadaan ketidakmampuan untuk mambayar debitur baik orangperorangan, maupun badan hukum atas utang-utangnya yang telah jatuh tempo, dan ketidak mampuan tersebut harus diajukan baik oleh debitur sendiri

\footnotetext{
${ }^{4}$ Munir Fuady, Hukum Pailit 1998 Dalam

Teori dan Praktek, Cet. Pertama, Citra Aditya Bakti, Bandung, 1999, Hal. 8
} 
maupun atas permohonan kreditur dan atas permohonan tersebut dinyatakan dalam putusan pengadilan. Dengan demikian, lembaga kepailitan hanya diperuntukkan dalam penyelesaian utang piutang antara Debitur dengan Kreditur.

Kepustakaan Common Law mengintrodusir istilah Bankruptcy yang juga bermakna Kepailitan. Penggunaan kata Bankruptcy dari kepustakaan Common Law sering disamakan dan dipertukarkan pemakaiannya dengan kata atau istilah Insolvency yang keduanya diartikan sebagai Kepailitan. Dalam Faillissement Verordening juga dijumpai istilah Insolvency yang berasal dari istilah Insolventie.

Menurut Kamus Hukum Ekonomi ELIPS, Insolvabel atau Insolevency atau Insolven adalah ketidak mampuan seseorang atau badan usaha untuk membayar hutangnya yang telah jatuh tempo, atau keadaan yang menunjukkan jumlah pasiva melebihi jumlah aktiva.

\section{PEMBAHASAN}

\section{Pengertian Kreditur dan Debitur}

Dalam definisi debitur menurut Pasal 1 ayat (2) Undang-Undang Nomor 37 Tahun 2004 tentang Kepailitan dan PKPU adalah orang yang mempunyai utang karena perjanjian atau undang-undang yang pelunasannya dapat ditagih di muka pengadilan. Kreditur dalam UndangUndang Nomor 37 Tahun 2004 tentang Kepailitan dan PKPU Pasal 1 angka 2 adalah orang yang mempunyai piutang karena perjanjian atau undang-undang yang dapat ditagih di muka pengadilan. Selain itu adapun pengertian lain kreditur dan debitur yaitu Kreditur adalah pihak bank atau lembaga pembiayaan lainnya yang mempunyai piutang karena perjanjian atau undang- undang. 5 Debitur adalah orang atau badan usaha yang memilki hutang kepada bank atau lembaga pembiayaan lainnya karena perjanjian atau undangundang. 6 Dalam Undang-Undang Nomor 37 Tahun 2004 tentang Kepailitan dan PKPU ada 3 (tiga) jenis kreditor yaitu kreditor konkuren, kreditor separatis dan kreditor preferen.

Kreditur separatis adalah kreditor yang tidak terkena akibat kepailitan, artinya para kreditor separatis tetap dapat melaksanakan hak-hak eksekusinya meskipun debitornya telah dinyatakan pailit. ${ }^{7}$ Sedangkan yang dimaksud dengan kreditor preferen adalah kreditor yang memiliki piutangpiutang yang berkedudukan istimewa (privilege) sebagaimana ditentukan dalam Pasal 1139 dan Pasal 1149 KUH Perdata. Hak privilege merupakan hak istimewa yang didahulukan (dikecualikan) karena undang-undang atau ditentukan dalam perjanjian. Piutang yang pelunasannya harus didahulukan juga disebut dengan piutang preference atau piutang istimewa, sedangkan piutang yang pelunasannya diselesaikan menurut asas keseimbangan dinamakan piutang konkuren. Dan Kreditor Konkuren adalah kreditor yang mempunyai hak mendapatkan pelunasan secara bersama-sama tanpa hak yang didahulukan, dihitung besarnya piutang masing-masing terhadap piutang secara

\footnotetext{
${ }^{5}$ Riduan Tobink dan Bill Nikholaus, Kamus Istilah Perbankan, Atalya Rileni Sudeco, Jakarta, 2003, h.118.

${ }^{6}$ Ibid.

${ }^{7}$ Ivida Dewi Amrih Suci dan Herowati Poesoko, Hukum Kepailitan Kedudukan dan Hak Kreditor Separatis atas Benda Jaminan Debitor Pailit, Laksbang Pressindo, Yogyakarta, 2016, h.93.
} 
keseluruhan dari seluruh harta kekayaan debitor.

\section{Pengertian Novasi}

Novasi adalah penggantian perikatan lama dengan suatu perikatan yang baru. Kata menggantikan mengandung arti, bahwa perikatan yang lama sengaja dihapuskan dan sebagai gantinya dibuatkan perjanjian baru, yang melahirkan perikatan sebagai ganti yang lama, kata "sengaja dihapuskan" berarti, bahwa para pihak memang menghendakinya atau dengan perkataan lain didasarkan kepada kita, bahwa novasi selalu di perjanjikan. ${ }^{8}$ Berdasarkan Pasal 1413 KUH Perdata dijelaskan bahwa ada 3 (tiga) jalan untuk melakukan novasi, yaitu :

1) Bila seorang debitur membuat suatu perikatan utang baru untuk kepentingan kreditur yang menggantikan utang lama, yang dihapuskan karenanya;

2) Bila seorang debitur baru ditunjuk untuk menggantikan debitur lama, yang oleh kreditur dibebaskan dan perikatannya; dan

3) Bila sebagai akibat suatu persetujuan baru seorang kreditur baru ditunjuk untuk menggantikan kreditur lama, yang terhadapnya debitur dibebaskan dan perikatannya.

Dari uraian mengenai cara mengadakan novasi tersebut diatas dapat kita katakan, bahwa pada peristiwa yang kedua dan ketiga ada penggantian subjek perikatan bisa debitur bisa kreditur sehingga orang mengatakan bahwa peristiwa tersebut merupakan peristiwa novasi subjektif.

${ }^{8}$ J.Satrio, Cessie, Subrogatie, Novatie, Kompensatie \& Pencampuran Hutang, PT. Alumni, Bandung, 1999, h.100.
Dalam hal yang diganti adalah subjek debitur, debitur lama diganti dengan debitur baru maka kita katakan disana ada novasi subjektif pasif, sedangkan pada penggantian subjek kreditur, kita namakan novasi subjektif aktif. Karena Pasal 1413 ayat (2) dan (3) mengatur tentang novasi subjektif, maka orang menyimpulkan bahwa Pasal 1413 ayat (1) mengatur tentang novasi subjektif. Uraian tersebut diatas mengajarkan kepada kita bahwa undang-undang mengenai 3 (tiga) macam/kelompok novasi.

\section{Pengertian dan Dasar Hukum Kepailitan}

Dalam bahasa Perancis, istilah faillite artinya pemogokan atau kemacetan dalam melakukan pembayaran. Orang yang mogok atau macet atau berhenti membayar utangnya disebut dengan Le Faille. Sedangkan dalam bahasa Inggris digunakan istilah to fail dan kata di dalam bahasa Latin digunakan istilah failire. $^{9}$

Menurut Rachmadi Usman, Kepailitan adalah keadaan dimana seorang debitor tidak mampu melunasi hutanghutangnya pada saat hutang tersebut jatuh tempo. Pernyataan pailit tidak boleh diputuskan begitu saja, melainkan harus dinyatakan oleh pengadilan, baik atas permohonan sendiri maupun atas permintaan seseorang atau pihak ketiga. ${ }^{10}$

Sedangkan definisi Kepailitan dalam ketentuan Pasal 1 ayat (1) Undang-Undang Nomor 37 Tahun 2004 tentang Kepailitan dan PKPU yakni:

${ }^{9}$ Zainal Asikin, Hukum Kepailitan dan Penundaan Pembayaran di Indonesia, Rajawali Press, Jakarta, 2002, h. 26-27.

${ }^{10}$ Rachmadi Usman, Op.Cit, h. 12. 
"Kepailitan adalah sita umum atas semua kekayaan Debitor Pailit yang pengurusannya dan pemberesannya dilakukan oleh kurator di bawah pengawasan hakim pengawas sebagaimana di atur dalam UndangUndang ini".

Adapun dasar hukum bagi suatu kepailitan adalah sebagai berikut:

1. Undang-Undang Nomor 37 Tahun 2004 tentang Kepailitan dan PKPU;

2. KUH Perdata ;

3. Undang-Undang Nomor 40 Tahun 2007 tentang Perseroan Terbatas ;

4. Undang-Undang Nomor 4 Tahun 1996 tentang Hak Tanggungan ;

5. Undang-Undang Nomor 42 Tahun 1999 tentang Jaminan Fidusia ;

6. Peraturan Perundang-undangan di bidang Pasar Modal, Perbankan, BUMN ; dan

7. Undang-Undang Nomor 21 Tahun 2011 tentang Otoritas Jasa Keuangan.

\section{Pihak Pemohon Pailit}

Salah satu pihak yang terlibat dalam perkara kepailitan adalah pihak pemohon pailit, yakni pihak yang mengambil inisiatif untuk mengajukan permohonan pailit ke Pengadilan, yang dalam perkara biasa disebut sebagai pihak penggugat. Menurut Pasal 2 Undang-Undang Nomor 37 Tahun 2004 tentang Kepailitan dan PKPU maka yang dapat menjadi pemohon dalam suatu perkara pailit adalah salah satu dari pihak berikut :

a) Pemohon Pailit Debitor, ketentuan Pasal 2 ayat (1) Undang-Undang Kepailitan dan PKPU menyatakan bahwa "Debitor yang mempunyai dua atau lebih kreditor dan tidak membayar lunas sedikitnya satu utang yang telah jatuh waktu dan dapat ditagih, dinyatakan pailit oleh putusan pengadilan, baik atas permohonannya sendiri maupun atas permohonan satu atau lebih kreditornya". Berdasarkan ketentuan tersebut di atas, maka pihak yang dapat mengajukan permohonan pernyataan pailit kepada pengadilan niaga adalah pihak debitor sendiri dan satu atau lebih kreditor.

b) Pemohon Pailit Kreditor, Ketentuan mengenai satu atau lebih kreditor dapat mengajukan permohonan pernyataan pailit kepada pengadilan niaga adalah ketentuan Pasal 2 ayat (1) Undang-Undang Kepailitan dan PKPU sebagaimana debitor dapat mengajukan permohonan pernyataan pailit atas dirinya sendiri. Selama berlakunya Undang-Undang Nomor 4 Tahun 1998 tentang Kepailitan, permohonan pernyataan pailit pada umumnya diajukan oleh kreditor, baik kreditor yang merupakan perusahaan maupun kreditor perorangan. Dalam hukum kepailitan dikenal prinsip paritas creditorum, artinya bahwa semua kreditor konkuren mempunyai hak yang sama atas pembayaran piutangnya. Hasil kekayaan debitor yang telah dijual akan dibagikan secara seimbang dan proporsional menurut besarnya piutang mereka masing-masing, kecuali apabila diantara para kreditor tersebut terdapat alasan-alasan yang sah untuk didahulukan karena kreditor tersebut memiliki hak jaminan kebendaan (secured creditor) atau kreditor tersebut memiliki preferensi untuk diistimewakan. ${ }^{11}$

c) Pemohon Pailit Bank Oleh Bank Indonesia, permohonan pernyataan pailit terhadap debitor yang

\footnotetext{
${ }^{11}$ Ibid, h.42-43.
} 
merupakan bank hanya dapat diajukan oleh Bank Indonesia sebagaimana yang dimaksud dalam Pasal 2 ayat (3) Undang-Undang Kepailitan dan PKPU. Menurut penjelasan Pasal 2 ayat (3) tersebut yang dimaksdud dengan "bank" adalah sebagaimana yang diatur dalam peraturan perundangundangan. Menurut Undang-Undang Nomor 7 Tahun 1992 tentang Perbankan sebagaimana yang telah diubah dengan Undang-Undang Nomor 10 Tahun 1998, bank adalah badan usaha yang menghimpun dana dari masyarakat dalam bentuk simpanan dan menyalurkannya kepada masyarakat dalam rangka meningkatkan taraf hidup rakyat banyak.

d) Pemohon Pailit Oleh Kejaksaan, permohonan pernyataan pailit juga dapat diajukan oleh kejaksaan untuk kepentingan umum sebagaimana yang telah diatur dalam UndangUndang Kepailitan dan PKPU juncto Peraturan Pemerintah Nomor 17 Tahun 2000 tentang Permohonan Pernyataan Pailit untuk Kepentingan Umum. Dalam Undang-Undang Kepailitan dan PKPU terdapat beberapa kewenangan kejaksaan dalam kepailitan.

\section{Pengertian dan Pengaturan Penundaan Kewajiban Pembayaran Utang (PKPU)}

Penundaan

Kewajiban

Pembayaran Utang (PKPU) adalah suatu masa yang diberikan oleh Undang-Undang melalui hakim Pengadilan Niaga yang dimana dalam masa tersebut kreditor dan debitor diberikan kesempatan untuk memusyawarahkan cara- cara pembayaran utang debitor dengan cara memberikan rencana pembayaran seluruh atau sebagian utangnya, termasuk apabila perlu untuk merestrukturisasi utangnya tersebut. ${ }^{12}$ PKPU bertujuan untuk memberikan kesempatan kepada debitor agar dapat menlanjutkan usahanya dan mempertahankan kekayaannya PKPU juga dimaksudkan agar kreditor memperoleh kepastian mengenai tagihannya, utang piutangnya akan dilunasi oleh debitor. PKPU itu sendiri berbeda dengan kepailitan. Walaupun dalam kepailitan ada dikenal perdamaian, namun pada dasarnya kepailitan itu ditujukan pada pemberesan harta pailit yang dilakukan dengan cara menjual seluruh boedel pailit dan membagikan hasil penjualan tersebut kepada para kreditor yang berhak menurut urutan yang ditentukan dalam undang-undang. ${ }^{13}$ Dalam hal ini terlihat bahwa kepailitan berujung pada tindakan likuidasi harta debitor. Sedangkan dalam PKPU, debitor diberikan kesempatan untuk melakukan negosiasi dengan kreditor untuk membahas kelanjutan utang piutang di antara mereka sehingga pada akhirnya tidak terjadi pemberesan harta pailit. Selama proses PKPU berlangsung pun debitor tetap menguasai hartanya, tidak seperti halnya yang terjadi dalam perkara permohonan pernyataan pailit. Dalam pengajuan PKPU, terdapat dua macam dijatuhkannya PKPU bagi debitor yaitu:

a. PKPU Sementara, Sebelum Pengadilan Niaga memutuskan

12 Munir Fuady, Hukum Pailit dalam Teori dan Praktek, PT Sinar Aditya Bakti, Bandung, 2014, h. 98.

13 Man S. Sastrawidjaja, Hukum Kepailitan dan Penundaan Kewajiban Pembayaran Utang, Alumni, Bandung, 2010. h. 202. 
untuk mengadakan pemberian PKPU Tetap, baik debitor maupun kreditor dapat mengajukan untuk diberikan putusan PKPU Sementara. ${ }^{14}$ PKPU sementara terjadi apabila pendaftaran diterima dan ditetapkan sebelum sidang di Pengadilan Niaga dimulai. Debitor dan kreditor dapat melakukan permohonan PKPU, apabila debitor yang mengajukan permohonan tersebut maka paling lambat 3 (tiga) hari pengadilan harus mengabulkan permohonan tersebut, kemudian Pengadilan Niaga akan menunjuk hakim pengawas serta mengangkat satu pengurus untuk mengurus kekayaan debitor. Apabila yang mengajukan permohonan adalah kreditor maka Pengadilan Niaga harus mengabulkannya paling lambat 20 (dua puluh) hari sejak permohonan PKPU tersebut didaftarkan. Apabila permohonan dikabulkan tahap selanjutnya adalah Pengadilan Niaga melalui pengurus menghadirkan debitor dan kreditor atas permohonan tersebut, jika debitor tidak hadir maka langsung dipailitkan dan PKPU sementara dianggap telah berakhir.

b. PKPU tetap, ini lahir setelah proses sidang dari PKPU sementara, dalam waktu 45 (empat puluh lima) hari setelah permohonan diterima harus dilakukan proses sidang, begitu juga dengan rencana perdamaian. PKPU tetap merupakan kelanjutan dari PKPU sementara, PKPU harus ditetapkan oleh Pengadilan Niaga dalam waktu 45 (empat puluh lima) hari sejak PKPU sementara diucapkan, apabila belum ditetapkan dalam jangka waktu tersebut maka

${ }^{14}$ Sutan Remy Sjahdeini, Op.Cit., h. 342. debitor akan dinyatakan pailit. Menurut Pasal 228 ayat (6) UndangUndang Nomor 37 Tahun 2004 waktu penundaan yang diberikan (termasuk perpanjanganya) selama PKPU adalah 270 (dua ratus tujuh puluh) hari sejak putusan PKPU Sementara diucapkan. Dengan berlakunya PKPU tetap ini, debitor, pengurus, dan kreditor mempunyai kesempatan untuk mempertimbangkan dan menyetujui rencana perdamaian pada rapat atau sidang yang diadakan selanjutnya selama periode PKPU tetap masih berlangsung. Dalam hal ini terlihat bahwa pada dasarnya PKPU tetap merupakan suatu periode yang dimiliki oleh debitor dan kreditor untuk melakukan perundingan guna mempertimbangkan rencana perdamaian, apakah diterima atau ditolak.

Pemberian PKPU Tetap berikut perpanjangannya akan berakhir dengan sidang pengesahan perdamaian yang telah diterima oleh kreditor, yang memungkinkan pula adanya penolakan pengesahan oleh Pengadilan dengan adanya alasan sebagaimana ditentukan oleh Pasal 285 ayat (2) UndangUndang Nomor 37 Tahun 2004 yang dapat mengakibatkan pailitnya debitor. Apabila rapat para kreditor tidak menghasilkan keputusan penerimaan atas rencana perdamaian sampai periode PKPU Tetap dan perpanjanganya berakhir, maka PKPU Tetap pun akan berakhir dengan dijatuhinya putusan pailit terhadap debitor.

Setelah diterimanya surat permohonan PKPU maka Pengadilan Niaga segera mengabulkan, dalam melaksanakan PKPU tersebut 
pengadilan akan menunjuk hakim pengawas serta mengangkat seorang atau lebih sebagai pengurus. Pengadilan Niaga tidak dapat menerima permohonan PKPU apabila surat tidak ditanda tangani sebagaimana mestinya atau tidak disertai surat-surat, hal ini diatur dalam Pasal 224 ayat (1). Dikabulkannya permohonan PKPU maka kekayaan debitor berada dalam pengawasan pengurus, debitor tidak berwenang melakukan kepengurusan dan pengalihan berkenaan dengan kekayaannya. ${ }^{15}$

\section{Perikatan dengan Ancaman Hukuman (Strafbeding)}

Perikatan dengan penetapan hukum (strafbeding), adalah untuk mencegah jangan sampai ia berhutang dengan mudah saja melalaikan kewajibannya, dalam praktek banyak hukuman, apabila ia tidak menepati kewajibannya. Hukuman ini, biasanya ditetapkan dalam suatu jumlah uang tertentu yang sebenarnya merupakan suatu pembayaran kerugian yang sejak semula sudah ditetapkan sendiri oleh para pihak yang membuat perjanjian itu. Hakim mempunyai kekuasaan untuk meringankan hukuman apabila perjanjian telah sebahagian dipenuhi. Dalam Pasal 1304 KUH Perdata memuat suatu penentuan arti (difinitie) dari sifat ancaman hukuman yang dijanjikan dalam suatu perjanjian, pasal tersebut berbunyi "Perjanjian hukuman adalah suatu perjanjian yang menempatkan seseorang sebagai

15 R. Anton Suyatno, Pemanfaatan Penundaan Kewajiban Pembayaran Utang Sebagai Upaya Mencegah Kepailitan, Edisi Pertama, Kencana Preneda Media Group, Jakarta, 2017, h. 52. jaminan pelaksanaan suatu perikatan yang mewajibkannya melakukan sesuatu, jika ia tidak melaksanakan hal itu."

Pasal $230 \quad$ Undang-Undang Nomor 37 Tahun 2004 disebutkan bahwa :

1) Apabila jangka waktu penundaan kewajiban pembayaran utang sementara berakhir, karena Kreditor tidak menyetujui pemberian penundaan kewajiban pembayaran utang tetap atau perpanjangannya sudah diberikan, tetapi sampai dengan batas waktu sebagaimana dimaksud dalam Pasal 228 ayat (6) belum tercapai persetujuan terhadap rencana perdamaian, pengurus pada hari berakhirnya waktu tersebut wajib memberitahukan hal itu melalui Hakim Pengawas kepada Pengadilan yang harus menyatakan Debitor Pailit paling lambat pada hari berikutnya; dan

2) Pengurus wajib mengumumkan hal sebagaimana dimaksud pada ayat (1) dalam surat kabar harian di mana permohonan penundaan kewajiban pembayaran utang sementara diumumkan berdasarkan Pasal 226

Dan berdasarkan Tambahan Lembaran Negara Republik Indonesia, penjelasan atas Undang-Undang Republik Indonesia Nomor 37 Tahun 2004 tentang Kepailitan dan PKPU menerangkan :

Pasal 230 ayat (1) :

Persetujuan terhadap rencana perdamaian harus dicapai paling lambat pada hari ke-270 (dua ratus tujuh puluh) sedangkan pengesahan perdamaian dapat diberikan sesudahnya.

Pasal 230 ayat (2) : 
Bagi Debitor, hal ini merupakan konsekuensi dari ketentuan pasal ini yang menentukan bahwa dalam hal permohonan penundaan kewajiban pembayaran utang tetap ditolak maka Pengadilan harus menyatakan Debitor Pailit. Seimbang dengan hal tersebut maka apabila permohonan penundaan kewajiban pembayaran utang tetap dikabulkan, Kreditor yang tidak menyetujuinya juga tidak lagi dapat mengajukan upaya hukum kasasi.

Dalam Pasal tersebut memuat sifat perjanjian dengan ancaman hukuman (strafbeding), yang mana apabila perjanjian dalam homologasi tersebut tidak dilaksanakan sebagaimana mestinya maka debitor akan menerima hukuman yaitu kepailitan terhadap dirinya.

\section{Syarat Mengajukan Permohonan Pailit}

Untuk dapat mengajukan permohonan kepailitan terhadap Debitor haruslah memenuhi syaratsyarat yang telah di tentukan dalam ketentuan UndangUndang Nomor 37 Tahun 2004 tentang Kepailitan dan PKPU Pasal 2 ayat (1) syarat pengajuan pailit yakni:

a. Syarat paling sedikit harus ada 2 (dua) Kreditur, menurut Pasal 2 ayat (1) Undang-Undang Kepailitan, salah satu syarat yang harus dipenuhi ialah debitur harus mempunyai dua kreditur atau lebih. Undang-Undang ini hanya memungkinkan seorang debitur dinyatakan pailit apabila debitur memiliki paling sedikit dua kreditur. Syarat mengenai adanya minimal dua atau lebih kreditur dikenal sebagai concursus creditorium. ${ }^{16}$

b. Syarat adanya Utang, dalam ketentuan Pasal 1 angka 6 UndangUndang Kepailitan dan PKPU, telah dirumuskan mengenai utang, yaitu: "Kewajiban yang dinyatakan atau dapat dinyatakan dalam jumlah uang baik dalam mata uang Indonesia maupun mata uang asing, baik secara langsung maupun yang akan timbul dikemudian hari atau kontijen, yang timbul karena perjanjian dari Undang-Undang dan yang wajib dipenuhi oleh debitur dan bila tidak dipenuhi memberi hak kepada kreditur untuk mendapat pemenuhannya dari harta kekayaan debitur".

Para pihak yang mengajukan permohonan pailit harus dapat membuktikan bahwa debitur mempunyai utang kepadanya. Para pihak yang dimaksud ialah (penasihat hukum) dari kreditur, (penasihat hukum dari) debitur, dan Majelis Hakim yang memeriksa permohonan itu, baik Majelis Hakim pengadilan niaga, Majelis Hakim kasasi, maupun Majelis Hakim peninjauan kembali. ${ }^{17}$

c. Salah satu utang telah jatuh waktu dan dapat ditagih, utang yang telah jatuh waktu dan dapat ditagih telah dirumuskan dalam penjelasan Pasal 2 ayat (1) yaitu kewajiban untuk membayar utang yang telah jatuh waktu, baik karena telah diperjanjikan, karena percepatan waktu penagihannya sebagaimana diperjanjikan, karena pengenaan

16 Sutan Remy Sjahdeny, Hukum Kepailitan, Pustaka Utama Grafiti, Jakarta, 2002, h.64.

${ }^{17}$ Sutan Remy Sjahdeny. Op. Cit, h. 68. 
sanksi atau denda oleh instansi yang berwenang, maupun karena Putusan Pengadilan, arbiter, atau majelis arbitrase. Syarat bahwa utang harus telah jatuh waktu, dapat ditagih menunjukan bahwa kreditur sudah mempunyai hak untuk menuntut debitur untuk memenuhi prestasinya. ${ }^{18}$

\section{Prosedur Pengajuan Kepailitan}

Pasal 2 ayat (1) Undang-Undang
Kepailitan dan PKPU telah memberikan ketentuan-ketentuan yang berkaitan dengan kewenangan Pengadilan Niaga dalam memutus permohonan pernyataan pailit.

Prosedur pengajuan permohonan pailit diatur dalam Pasal 6 sampai dengan Pasal 10 Undang-Undang Kepailitan dan PKPU, kemudian mengenai prosedur Upaya Hukum setelah putusan dijatuhkan, diatur dalam Pasal 11 sampai dengan Pasal 14 Undang-Undang Kepailitan dan PKPU. Dalam perkara kepailitan, setelah pendaftaran pengajuan permohonan pailit diterima oleh panitera dan diajukan ke Ketua Pengadilan Niaga, maka akan ditetapkan hari sidang dan menuju ke proses persidangan. Sama halnya dengan perkara pidana atau perdata yang dalam persidangan yang dikenal adanya "pembuktian". Dalam perkara kepailitan terdapat suatu asas dalam pembuktian yaitu "asas pembuktian sederhana". Hal ini diatur dalam Pasal 8 ayat (4) Undang-Undang Kepailitan dan PKPU.

Pernyataan pailit seorang Debitor dilakukan oleh Hakim pengadilan Niaga dengan suatu putusan (vonnis) dan tidak dengan suatu ketetapan (beschikking). Hal itu disebabkan suatu putusan menimbulkan suatu akibat

\footnotetext{
${ }^{18}$ Jono, Op.Cit, h.11.
}

hukum baru, sedangkan ketetapan tidak menimbulkan akibat hukum yang baru tetapi hanya bersifat deklarator saja. Pernyataan pailit menimbulkan suatu akibat hukum yang baru seperti antara lain Debitor yang semula berwenang mengurus dan menguasai hartanya menjadi tidak berwenang mengurus dan menguasai hartanya.

\section{Upaya Hukum}

Dalam perkara Kepailitan,tidak mengenal adanya upaya hukum banding, tetapi hanya ada upaya hukum Kasasi dan Peninjauan Kembali. Perkataan kasasi berasal dari perkataan Perancis "casser" yang berarti memecahkan atau membatalkan, sehingga apabila suatu permohonan kasasi terhadap putusan Pengadilan bawahan itu diterima oleh Mahkamah Agung, maka hal itu berarti bahwa putusan tersebut dibatalkan oleh Mahkamah agung karena dianggap mengandung kesalahan dalam penerapan hukumnya. ${ }^{19}$ Kasasi adalah tindakan Mahkamah Agung untuk menegakkan dan membetulkan hukum, jika hukum ditentang oleh putusanputusan hakim pada tingkatan tertinggi. ${ }^{20}$

Terhadap putusan Pengadilan yang telah memperoleh kekuatan hukum tetap, pihak-pihak yang bersangkutan dapat mengajukan peninjauan kembali kepada Mahkamah Agung, apabila terdapat hal atau keadaan tertentu yang ditentukan dalam Undang-Undang. Bahwa yang dimaksud dengan "hal atau keadaan tertentu" antara lain adalah

19 Subekti, Kekuasaan Mahkamah Agung Republik Indonesia, Alumni, Bandung, 1980, h. 1-2.

20 Supomo, Hukum Acara Perdata Pengadilan Negeri, Fasco, Jakarta, 1958, h. 168169. 
ditemukannya bukti baru (novum) dan /atau adanya kekhilafan atau kekeliruan Hakim dalam menerapkan hukumnya. ${ }^{21}$

\section{E. KESIMPULAN}

Dalam kepailitan harus diketahui dengan jelas kedudukan antara para pihak sebagai kreditur dan debitur dalam novasi, hal ini sangat urgent dan penting karena untuk dapat memenuhi syarat dalam penjatuhan kepailitan menurut Undang-Undang Nomor 37 Tahun 2004, dimana syarat tersebut mengharuskan adanya minimal berapa kreditur dan debitur dan jika kedudukan antara para pihak tidak jelas dalam sengketa a quo maka syarat penjatuhan PKPU dan Kepailitan tidak dapat dilaksanakan.

Dalam Undang-Undang Nomor 37 Tahun 2004, penjatuhan pailit pada para pihak yang dimohonkan pailit dapat dengan beberapa cara, dimana proses tersebut dapat dengan dimohonkan pailit sekaligus atau ada juga yang ingin berdamai, namun dengan adanya klausula perdamaian tersebut tidak secara serta merta tidak dapat dipailitkan, justru jika perjanjian perdamaian tersebut tidak dilaksanakan maka kepailitan dapat dilakukan langsung tanpa adanya proses di pengadilan lagi, hal ini tertuang dalam Pasal 230 terutama pada ayat (1) dalam Undang-Undang Kepailitan dan PKPU, ini sebabkan karena para pemikir Undang-Undang Nomor 37 Tahun 2004 menyatakan dalam Buku Kompilasi Risalah atau Memorie van Toelichting (MvT) dalam undangundang tersebut, agar proses perdamaian tersebut benar-benar menjadi iktikad baik untuk pembayaran utang bukan hanya sebagai lips service atau bumbu pemanis dalam pembayaran utang itu sendiri. Pasal 230 ini dapat disalahgunakan oleh orang hukum yang hanya ingin "memailitkan" pihak lain, yang sebenarnya dalam perkara a quo bisa membayar hutang namun deviden yang di bayarkannya hanya terlambat untuk memenuhi prestasinya, jika itu terjadi maka kewenangan sebenarnya terletak di Pengadilan Negeri bukan Pengadilan Niaga karena sengketa tersebut pada dasarnya hanyalah wanprestasi bukanlah kepailitan.

\section{F. DAFTAR BACAAN}

\section{Buku-Buku}

Asikin Zainal, Hukum Kepailitan dan Penundaan Pembayaran di Indonesia, Jakarta: Rajawali Press, 2002.

Badrulzaman, Mariam Darus, Kitab Undang-Undang Hukum Perdata Buku III tentang Perikatan dengan Penjelasan, PT. Alumni, Bandung, 2005.

Fuady, Munir, Hukum Pailit dalam Teori dan Praktek, PT Sinar Aditya Bakti, Bandung, 2014.

Budiono Herlien, Ajaran Umum Hukum Perjanjian dan Penerapannya di Bidang Kenotariatan, PT Citra Aditya Bakti, Bandung, 2011.

Ginting, Elyta Ras, Hukum Kepailitan Teori Kepailitan, Sinar Grafika, Jakarta, 2018.

Hasbullah, Frieda Husni, Hukum Kebendaan Perdata: Hak-Hak Yang Memberi Kenikmatan, Penerbit Ind-Hil-Co Jakarta, 2005.

HS, Salim, Hukum Kontrak : Teori dan Teknik Penyusunan Kontrak, Sinar Grafika, Jakarta, 2003. 
Jono, Hukum Kepailitan, Sinar Grafika, Jakarta, 2008.

Poerwadarminta, W.J.S. Kamus Umum Bahasa Indonesia, Edisi Ketiga, Diolah Kembali oleh Pusat Bahasa Departemen Pendidikan Nasional, Balai Pustaka, Jakarta, 2005.

Prodjodikoro, Wirjono, Hukum Perdata Tentang PersetujuanPersetujuan Tertentu, Vorkinkvan Hoeve, Bandung, 1959

Suci , Ivida Dewi Amrih \& Herowati Poesoko, Hukum Kepailitan Kedudukan dan Hak Kreditor Separatis atas Benda Jaminan Debitor Pailit, Laksbang Pressindo, Yogyakarta, 2016.

Satrio, J. Cessie, Subrogatie, Novatie, Kompensatie \& Pencampuran Hutang, PT. Alumni, Bandung, 1999.

Sastrawidjaja, Man. S. Hukum Kepailitan dan Penundaan Kewajiban Pembayaran Utang, Alumni, Bandung, 2010.

Suyatno, R. Anton, Pemanfaatan Penundaan Kewajiban Pembayaran Utang Sebagai Upaya Mencegah Kepailitan, Edisi Pertama, Kencana Preneda Media Group, Jakarta, 2017.

Usman, Rachmadi, Aspek-Aspek Hukum Perbankan di Indonesia, PT Gramedia Pustaka Utama, Jakarta, 2001.

-Dimensi Hukum Kepailitan di Indonesia, Gramedia Pustaka Utama, Jakarta, 2004.

Tobink , Riduan \& Bill Nikholaus, , Kamus Istilah Perbankan, Atalya Rileni Sudeco, Jakarta, 2003.

Simanjuntak Ricardo, Hukum Kontrak: Teknik Perancangan Kontrak Bisnis, Gramedia, Jakarta, 2010.
Subekti, Hukum Perjanjian, Intermasa, Jakarta, 2005.

Subekti, - Aneka Perjanjian, cetakan kesepuluh, PT.Citra Aditya Bakti, Bandung, 1995.

Subekti, - Kekuasaan Mahkamah Agung Republik Indonesia, Alumni, Bandung, 1980.

Supomo, Hukum Acara Perdata Pengadilan Negeri, Fasco, Jakarta, 1958.

Sudikno Mertokusumo, Hukum acara Perdata Indonesia, Liberty, Yogjakarta, 2006.

Suharnoko \& Endah Hartati, Doktrin Subrograsi, Novasi dan Cessie dalam Kitab Undang-Undang Hukum Perdata, Nieuw Nederlands Burgerlijk Wetboek, Code Civil Perancis, dan Common Law, Kencana Prenada Media Group, Jakarta, 2005.

Sunarmi, Hukum Kepailitan, Edisi 2, PT. Sofmedia, Jakarta, 2010.

Sjahdeini, Sutan Remy, Hukum Kepailitan; Memahami UndangUndang Nomor 37 Tahun 2004 Tentang Kepailitan, Pustaka Utama Grafiti, Jakarta, 2010.

Hukum Kepailitan, Pustaka Utama Grafiti, Jakarta: 2002.

Widjaja Gunawan, Tanggung Jawab Direksi atas Kepailitan Perseroan. Jakarta: PT. Raja Grafindo Persada, 2002.

Peraturan dan PerundangUndangan

Undang-Undang Nomor 37 Tahun 2004 tentang Kepailitan dan Kewajiban Pembayaran Utang .

Kitab Undang-Undang Hukum Perdata (Burgerlijk Wetboek voor Indonesie) .

Undang-Undang Republik Indonesia Nomor 40 Tahun 2007 tentang Perseroan Terbatas. 
Peraturan Pemerintah Nomor 17 Tahun 2000 tentang Permohonan Pernyataan Pailit .

Tambahan Lembaran Negara Republik Indonesia Nomor 4443 (Penjelasan Atas Lembaran Negara Tahun 2004 Nomor 131) Penjelasan Atas Undang-Undang Republik Indonesia Nomor 37 Tahun 2004 Tentang Kepailitan Dan Penundaan Kewajiban Pembayaran Utang

\section{Skripsi dan Thesis}

Alin Husnul Khotimah, Permohonan Pembatalan Homologasi Oleh Kreditor Tidak Terdaftar, Program Studi S1 Ilmu Hukum Fakultas Hukum Universitas Islam Indonesia, Yogyakarta, 2018.

Marthasia

Kusumaningrum, Perkembangan Pengertian Utang Menurut Undang-Undang Kepailitan Di Indonesia, Program Studi Magister Kenotariatan Universitas Diponegoro, Semarang, 2011,

Indriyani Widyastuti, Novasi Subyektif Pasif Karena Meninggalnya Debitur Pada Pt Bank Mandiri (Persero) Cabang Pemuda Semarang, Program Studi Magister Kenotariatan Universitas Diponegoro, Semarang, 2010.

\section{Jurnal dan Makalah}

Jurnal Repertarium, Problematika Yuridis Pelaksanaan Novasi Subjektif Pasif dalam Perjanjian Kredit Karena Pemberi Hak Tanggungan Meninggal Dunia, Fakultas Hukum Universitas Sebelas Maret, Solo, 03 Januari 2015.

Lex et Societatis, Akibat Hukum Terhadap Penjatuhan Pailit
Pada Perseroan Terbatas (PT), Volume III Nomor 4/Mei/2015. Paulus E. Lotulung, Pengertian Pembuktian Secara sederhana dalam Kepailitan, Majalah Ombudsman Nomor 54/V/2004. 